\title{
REPORT FROM THE WRITERS' CONVENTION
}

Someone said the Eskimos have thirteen words for snow, but someone else said No, they have twenty-three, and someone else insisted it was thirty-seven, the point being that anyone who has a word for something we don't have a word for is infinitely superior, nobler, purer, more capable of peace and disarmament, eating good stuff all the time and unthinkingly sexual.

Someone mentioned again that the Chinese already had many things we invented centuries later, and someone gave us the usual lecture on the Chinese ideogram, "sincerity" being "a man" (literally) "standing by his word," the point being that all other languages are superior to one's own, embodying the best thought in the least action, historic, honest, elevated and utterly and deliberately sexual.

Someone told us that anyone who hopes to write must know half a dozen languages, but someone else said the important thing was to work at hard labor and avoid teaching or any kind of stipend, while another one said he could tell who among us hadn't climbed a mountain or yet built a house or been entirely lost or alone, the point being we had a long way to go to reach the beginning.

Someone said we were stupid if we thought our own language was good enough, and someone said Yes, or our own country, and someone else said that other people knew everything if we could only get to the bottom of Macchu Picchu, the point being that people are better if they aren't us and all of our poetry has already been written for us if we would just stop trying to make our own mistakes. 
Someone said that Russia practices the most censorship, and someone else said it was Central America, but someone insisted it was South Africa, and then there was agreement that it was all the doing of the United States anyway, except for the novelist from Yugoslavia who said government wasn't it and the subject should be, "Writers versus Writers." Anyway, the unanimous conclusion was that bad poetry is bad. 